\title{
THE OCCURRENCE OF MARINE ALGA ENTEROMORPHA INTESTINALIS IN WATER COURSES FROM SALT AREA MELEDIC PLATEAU, VRANCEI SUBCARPATHIANS (ROMANIA)
}

STRAT Daniela ${ }^{1}$

\begin{abstract}
Three new sites of Enteromorpha intestinalis have been found in the drainage basin of the Slănic River located in the Subcarpathians region, salt Meledic Plateau. E. intestinalis is a cosmopolitan macro green alga species with tubular thali that is primarily found in the coastal zone, including the Romanian Black Sea coast. Due to its salt tolerance this alga it was found in some inland waters, both fresh and saline waters courses and limnic waters that are often positively correlated with cultural eutrophication. These new reported localities of E. intestinalis in inland waters from this saline region contribute new and essential information about the distribution of this originally marine species on the inland area of Romania.

Keywords: Enteromorpha intestinalis (L.) Nees 1820, water courses, salt diapir, salt karst, Meledic Plateau, Slănic River
\end{abstract}

Received 13 October 2015

Accepted 11 December 2015

\section{Introduction}

Enteromorpha Link (1820), the gut weed, is one of the best known marine green algae genus. Its habit is easily recognizable: tubular thallus, gas or liquid-filled, with the wall of the tube made by a single cell layer. Initially, Enteromorpha grows attached to the substrate but then, mature thalli, filled with air, can become free floating. The thallus can be branched or unbranched and in case of some species it can reach until two meters in length and 1-1.5 cm wide (Horincar et al. 2011).

According to Index Nominum Algarum there are 135 Enteromorpha species (Hayden 2003). Additionally, there are subspecies, varieties and forms but they are very difficult to identify because morphological differences between taxa are often slight (Tan et al. 1999, Hayden et al. 2003, Leskinen \& Pamilo 1997, Leskinen et al. 2004).

Enteromorpha grows attached to the substrate by a disc like holdfast and the thallus of some species can reach until two meters in length (Horincar et al. 2011). Although, based on the gross morphology - tubular monostromatic thallus - Enteromorpha was considered for a long time a separate genus of green algae family Ulvaceae, molecular and culture data (Tan et al. 1999) fallowed by nuclear ribosomal internal transcribed spacer DNA analyses have provided strong evidence that Ulva and Enteromorpha genera are not distinct evolutionary entities and should not be recognized as separate genera. For this reason Enteromorpha must be reduced to synonymy with Ulva

\footnotetext{
${ }^{1}$ University of Bucharest, Faculty of Geography, 1 Nicolae Bălcescu Blvd., Sector 1, Bucharest, Romania, email: danielastrat@gmail.com
} 
as originally circumscribed by Linnaeus (1753) (Tan et al. 1999, Hayden et al. 2003). After the Enteromorpha genus was merged with Ulva by Hayden et al. (2003), in the last decades, an increasing number of authors in their papers has used synonym Ulva instead of Enteromorpha genus.

Few species of Enteromorpha, with distinctive hollow cylindrical thalli, can proliferate in inland waters (slow-flowing rivers, ponds and lakes) as a response to cultural eutrophication (Taft 1964, Pfiester et al. 1976, John et al. 2002, Messyasz \& Rybak 2009, Rybak et al. 2011). Also, few of them are cosmopolitan euhalinity species with a wide distribution in marine, freshwater and brackish water environments throughout the world like E. intestinalis (Black \& Weeks 1972, Pfiester et al. 1976, Vladimirescu 2007, Messyasz \& Rybak 2008, Messyasz 2009, Moore 2009), E. compressa (Messyasz 2009) and E. flexuosa subsp. pilifera (Mareš 2011). E. flexuosa subsp. pilifera (Kützing) M.J. Wynne 2005, which is a dominating taxon from the Enteromorpha genus in freshwater ecosystems of Europe (Messyasz et al. 2015), has been reported as an exclusively freshwater alga in Europe (Christensen 1994) and North America (John \& Rindi 2015). It is often present in nutrient-rich (eutrophic) ponds and lakes, commonly as free-living floating and irregularly wrinkled tubes with short uniseriate branches (Burkholder 2010). However, distinctly, all freshwater members of Enteromorpha genus are elongated, tubular and usually branched (John \& Rindi 2015).

Some studies emphasize that the occurrence of Enteromorpha species in different inland water bodies are very often associated with anthropogenic sodium chloride pollution and nutrient enrichment (Zimmermann-Timm 2007, Messyasz \& Rybak 2009, Messyasz \& Rybak 2011). Furthermore, during 20th century, freshwater Enteromorpha populations located in inland ecosystems that are not in contact with salt waters have been recorded in at least eight countries from worldwide (Messyasz \& Ryback 2011).

Also, marine species of Enteromorpha genus, especially E. intestinalis were reported in inland athalassic salty lakes (Savage 1964, Taft 1964, Pfiester et al. 1976, Conner et al. 1978, Hammer 1981, Reinke 1981, Hammer \& Heseltine 1988, Eimanifar \& Mohebbi 2007, Kaštovský et al. 2010, Gheorghievici et al. 2015, Messyasz et al. 2013), hypersaline springs and rivers (Velasco et al. 2006, Messyasz \& Rybak 2011, Millán et al. 2011), streams and lagoons receiving effluents from salt mines (John \& Rindi 2015). However, based on literature review, the most widespread species of Enteromorpha genus in inland waters is E. intestinalis. Both field and laboratory observations have showed that key chemical factors affecting colonization and growth of Ulva species in inland waters as well as the length, the wide and branching thallus are sodium chloride, phosphate and nitrite concentrations (Messyasz \& Rybak 2011). High concentrations of sodium chloride inhibit the development of Enteromorpha sp. while high nitrite concentrations were positively correlated with an increase in the number of thalli and the thalli length (Messyasz \& Rybak 2011).

In Romania, apart from the Black Sea coast (Cărăuşu 2012, Nastac et al. 2014), the occurrence of $E$. intestinalis was recorded both in inland freshwaters (Vladimirescu 2007, Cojocaru 2012) and athalassic (Gheorghievici et al. 2015) and anthroposaline lakes (Horotan 2010).

In this paper we report occurrence of macroalga Enteromorpha sp., tubular form thallus, in two rivers and one stream that drain a salt diapir from Vrancei Subcarpathians. A brief description of the habitat where it has been found is presented. 


\section{Material and methods}

In August and September 2014, during a geomorphological field work on Meledic Plateau, it were found typical vividly green tube shaped thalli of Enteromorpha in the Slănic River and the Meledic Stream. A year later, on 3 August, it was found Enteromorpha thalli in the superior course of the Jghiab Stream bed, a right side tributary of the Slănic River. For each occurrence geographical coordinates were recorded with GARMIN GPSMAP 64s. Macroscopic observations related to length, diameter, ramification, color, and general appearance of thalli were performed. Also, abiotic environment observations were made. A hand lens $(18 \mathrm{~mm}-10 \mathrm{X})$ was used to for complementary examination of thalli in the field.

\section{Results and discussion}

The Meledic Plateau Salt is located in the Vrancei Subcarpathians. From geological point of view, the plateau belongs to the Mânzălești salt formation that was accumulated in Early and Middle Miocene (Săndulescu 1984). The Meledic Plateau was cropped from a salt massif by four valleys: the Slănic River valley in the south, the Meledic Stream valley in the north, the Jghiab River valley in the east, and the Sărata Stream valley in the west (Fig. 1). On the south-west side of the Meledic Plateau, which corresponds to the right slope of the Slănic River valley, the salt massif or diapire outcrop is named Muntele de Sare. From it, salt springs that flow to the Slănic River generate salt crusts on the geographical left river bed side which are washed out during high flows. The salt is mixed with clays and salt breccia and covered by clays and other soft sedimentary rocks.

During rainy events, all salt outcrops are subjected to runoff and dissolution. The water with high dissolved salt load is collected by streams and drained to the marginal rivers and salt caves. Some caves drain directly to the margins of the plateau, which are the local base level of drainage. Except east edge of the plateau, from all other sides emerge brine springs that are directly and indirectly collected by Slănic River. Underground salt dissolution and suffusion has been generated caves and dolines which change the surface topography of the plateau. Above ground, many dolines have become freshwater lakes and small wetlands with a great biodiversity.

Because salt deposits are quite impure they are not economically valuable for exploitation. However, in the whole area the human pressures are low thus a great diversity of genuine salt karst features exists. Due to geological, geomorphological (Giurgiu 2010, Mărunțeanu \& Ioane 2010, Irimia \& Irimuş 2012) and biodiversity value (Sava et al. 2010) the west side of Meledic Plateau and a small section of Jghiab Valley, an area who covers 151 ha, was designed national protected area according to Law 5/2000 (Official Monitor 152/12.04. 2000). Later, in 2008, around $81 \%$ (136 ha) of the protected area became part of Site of Community Importance Platoul Meledic (ROSCI0199 Platoul Meledic), mainly because of the lepidoptera Lycaena dispar (Haworth 1803) and Ponto-Sarmatic deciduous thickets habitat, 40C $0 *$ code Natura 2000 (OM MMDD nr. 1964/2007).

The altitude of Meledic Plateau ranges between 450 and $600 \mathrm{~m}$. The climate is middle temperate. Average annual air temperature is $11^{\circ} \mathrm{C}$ and annual sum of precipitation is around $565 \mathrm{~mm}$ with torrential episodes during the summer. 


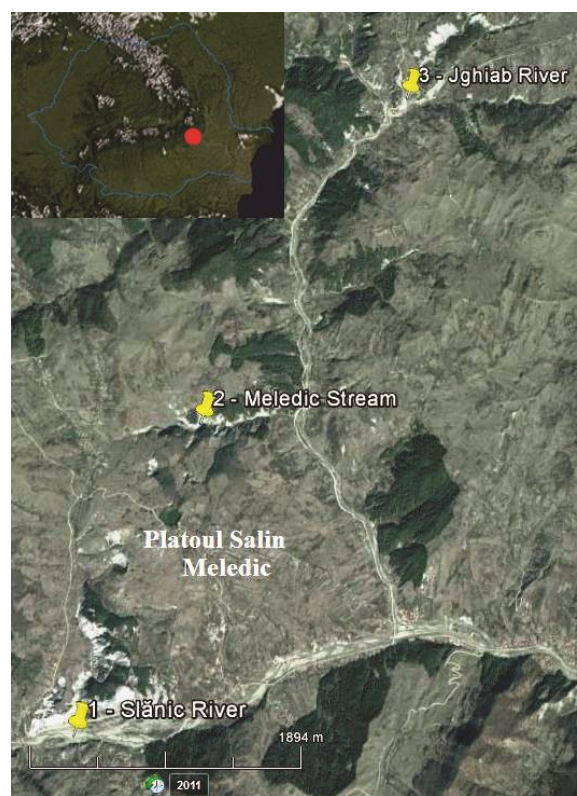

Fig. 1. The Meledic Plateau and the geographical position of sites with Enteromorpha intestinalis. 1 - The Slănic River; 2 - The Meledic Stream; 3 - The Jghiab River

\section{Occurrence sites of Enteromorpha intestinalis (L.) Nees 1820}

Green tube-shaped thalli of Enteromorpha sp. were found in three water courses from Meledic Plateau area (Fig. 1) that is located in Vrancei Subcarpathians. Based on gross observation of thalli, abiotic environment assessment (geological and geomorphological characteristics) and literature review we suggest this alga is $E$. intestinalis. The occurrence sites of this alga are:

1. The Slănic River site. Between Lopătari village and the confluence with the Jghiab River, the Slănic is a braided river. It is shallow and flows in two or more channels around alluvial (gravel and sand) exposed and submerged bars. Enteromorpha thalli were found in a subsidiary channel with slow flow, very close to right river bank that is made by salt. Because in vicinity of site there is a sheepfold, probably there is an input of nitrogen as a result of nitrate leaching from manure. Dense, branched and submerged thalli were attached to cobbles and pebbles (Fig. 2). Only few of them were free-floating and they have looked like intestinoid tubes with light green-yellow color. Most of thalli reached a length of up $50 \mathrm{~cm}$ and around $0.3-0.5 \mathrm{~cm}$ wide. Geographical coordinates of site with the occurrence of Enteromorpha are: $45^{\circ} 29^{\prime} 01^{\prime \prime} \mathrm{N}, 26^{\circ} 36^{\prime} 35^{\prime \prime} \mathrm{E}$, 433 m.a.s.1., opposite to the Săreni village.

2. The Meledic Stream site. In the Meledic stream (Figs 1, 3) Enteromorpha thalli were found along $200 \mathrm{~m}$ of course water in sheltered areas. There were found both types of thalli: attached to the substrate and as well as free-floating intestinoid clusters (Figs 4,5 ) in sheltered site sections with very slow flowing, almost stagnant, and soft river bed. Thalli were not branched. Their length ranged up to $1 \mathrm{~m}$ and the diameter was frequently $0.5 \mathrm{~cm}$. Thalli of Enteromorpha intestinalis occurred in water curse section when the Meledic Stream crosses salt deposits and salt springs flowing into its channel. In the upper catchment of the Meledic stream, upstream to occurrence of Ulva intestinalis, there are two sheepfolds (in area of Trestioara village) which contaminate 
water with manure. Geographical coordinates of the site (Fig. 1) are: $45^{\circ} 30^{\prime} 13^{\prime \prime} \mathrm{N}$, 263' 65"E, 488 m.a.s.l.

3. The Jghiab River site. Free-floating and attached Ulva thalli were found in milky water of the Jghiab River from its upper catchment, right upstream to the confluence with Bisocuța Stream (Fig. 1). River bed is covered by cobbles, boulders and clay. In this area, the Jghiab River has dissected a salt diapir that was exposed by erosion as outcrops on both sides of valley. Springs salt flow in river thereby contributing to change of sodium chloride concentrations of water. All thalli were poorly branched and rarely exceeded $1 \mathrm{~m}$ in length (Fig. 6). Geographical coordinates of the site are: $45^{\circ} 31^{\prime} 86^{\prime \prime} \mathrm{N}, 26^{\circ} 38^{\prime} 51$ "E, 483 m.a.s.1.

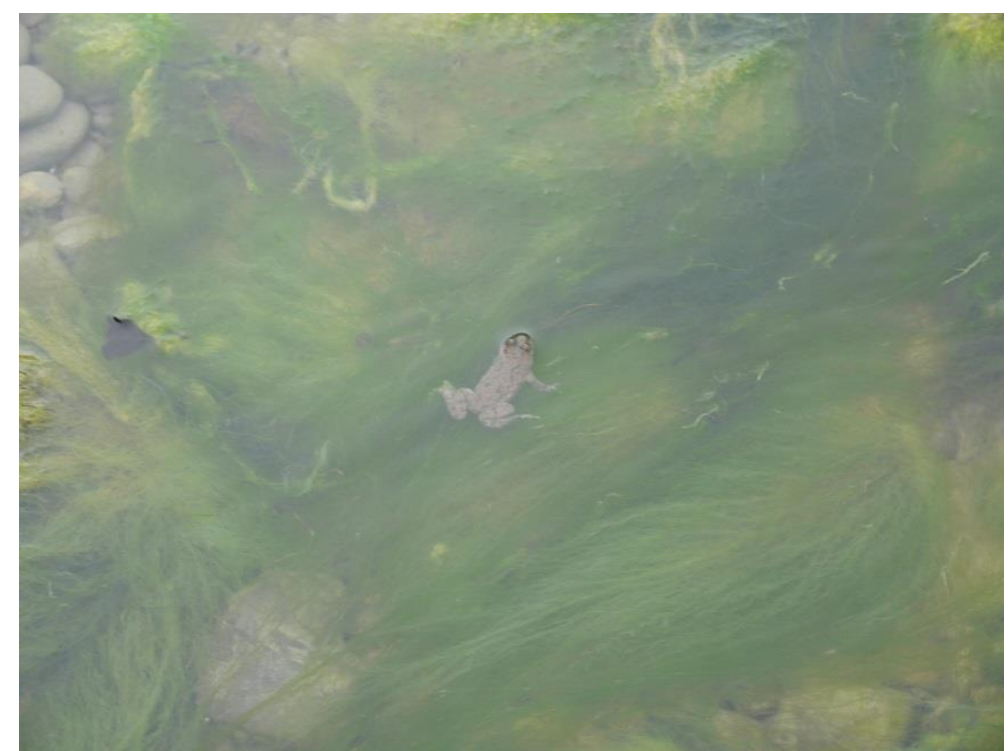

Fig. 2. Enteromorpha intestinalis attached to cobbles from river bed of subsidiary arm of the Slănic River. The amphibian is a Bombina sp.

\section{Conclusions}

Enteromorpha tubular thalli were found in three water courses from Vrancei Subcarpathians, Slănic upper drainage basin, the salt Meledic Plateau region. All sites are located in sections of water courses where they are naturally supplied with sodium chloride derived from dissolution of geological substratum (salt and saline rocks). Based on gross morphology, the tubular algal thalli belong to Enteromorpha intestinalis species and its occurrence in this area is supported by sodium chloride concentrations of water due to the chemical characteristics of the physical environment. Vectors who have contributed to migration of this marine species into inland waters from this area are unknown. However, observations on microscopic anatomy of thallus are further required in order to confirm the species identification. The occurrence of this marine macro alga in Meledic Plateau region adds value to the biodiversity of the two protected areas that were designed within - The Meledic Plateau Natural Reserve and the Natura 2000 site ROSCI0199 Meledic Plateau - that are partially overlapped. 


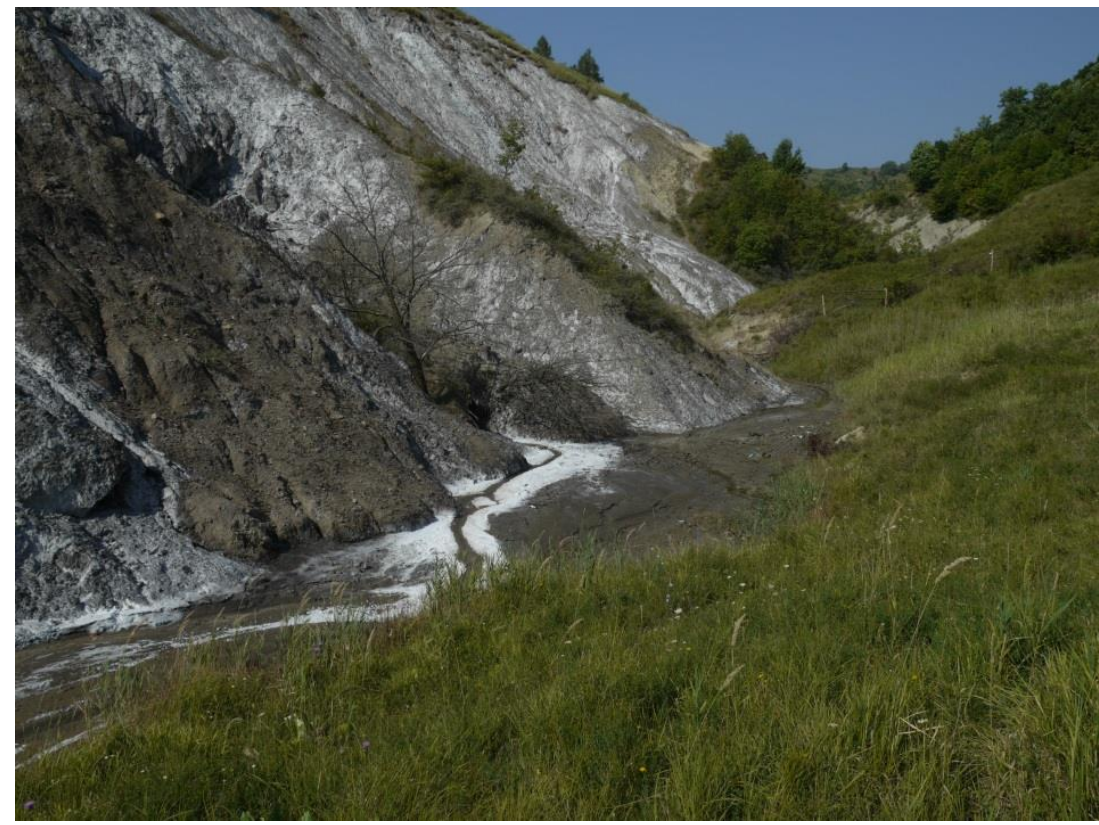

Fig. 3. The Meledic Stream valley - upstream view. The steep slope is an outcrop of salt diapir. During the time without rains, especially in the warm season, a salt crust appears along to the salty springs that flow into Meledic Stream

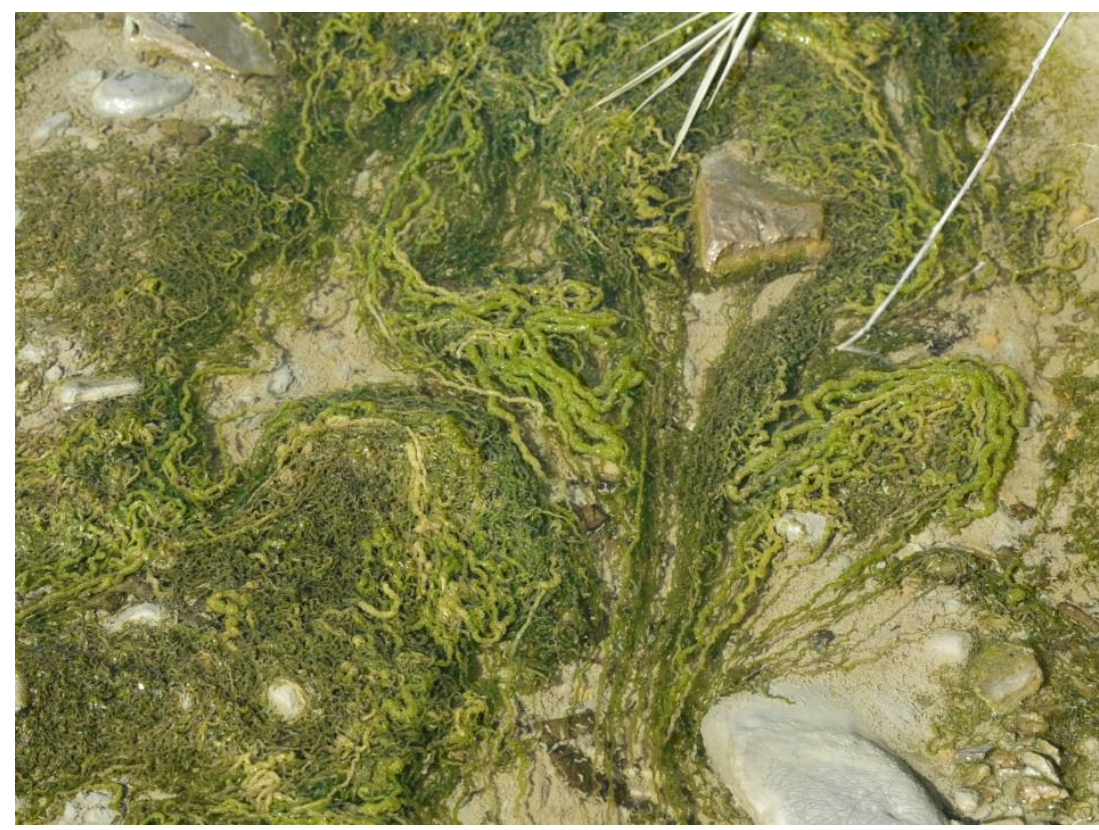

Fig. 4. Mat of Enteromorpha intestinalis thalli in Meledic Stream 


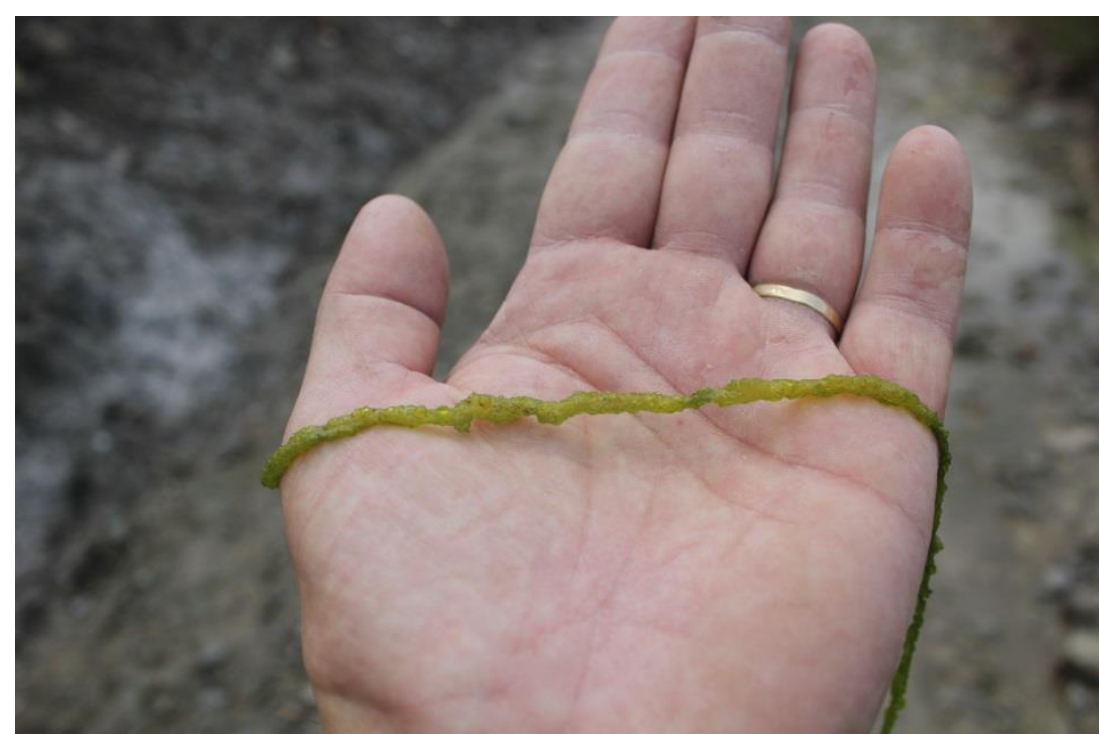

Fig. 5. Close view of E. intestinalis that was found in the Meledic Stream

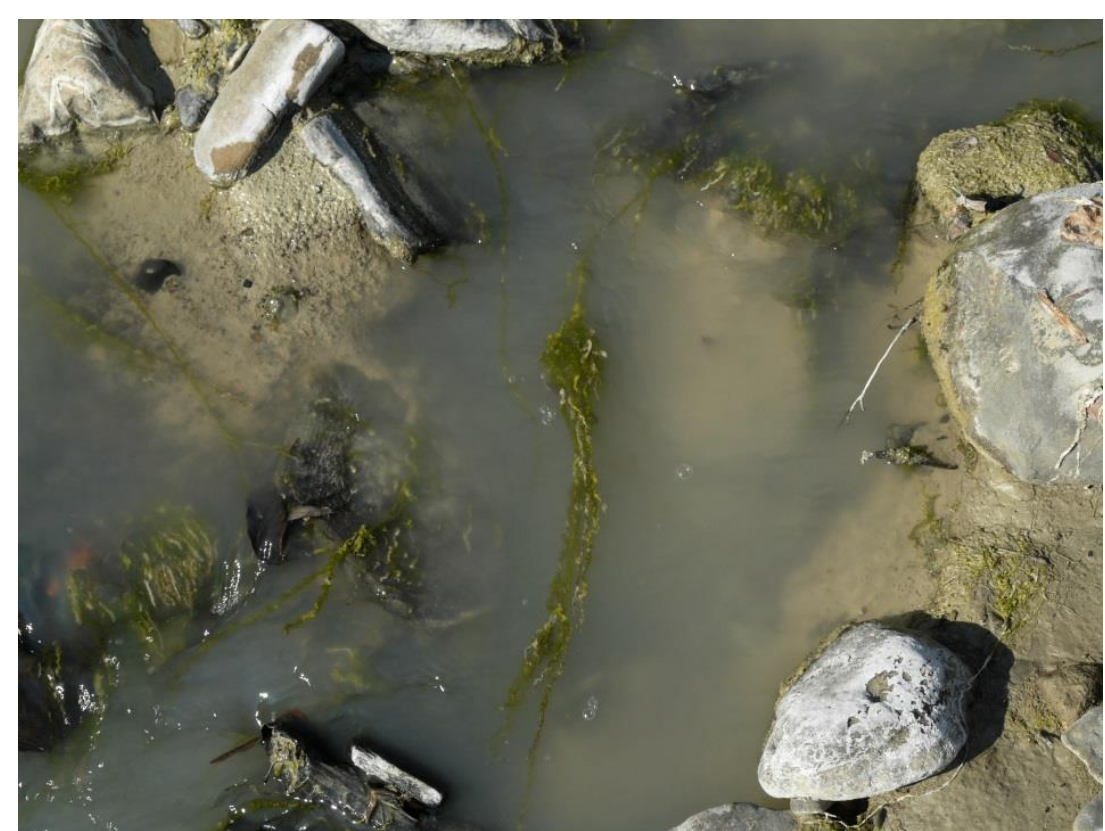

Fig. 6. Attached and free-floating thalli of E. intestinalis in the Jghiab River in the area where its water is enriched with natrium chloride provided by salt springs

\section{References}

Black, D. \& Weeks, D. (1972). Ionic relationships of Enteromorpha intestinalis. New Phytologist, 71, 119-127. 
Burkholder, J.M. (2010). Harmful algal blooms. In G.E. Likens (ed.), Plankton of Inland Waters (pp. 360-370). Amsterdam: Academic Press.

Cojocaru, I. (2012). Qualitative and quantitative analysis of the aquatic beetles cenosis in the Ciric lake (Iaşi) in 2012. Analele Științifice ale Universității „,Alexandru Ioan Cuza" din Iași, s. Biologie animală , 58, 43-52.

Conner, D., Huddleston, D., Pfiester, L. A. \& Thompson, S. (1978). A third species of Enteromorpha (a marine chlorophycean) for Oklahoma. Proceedings of the Oklahoma Academy of Science, 58, 110. Retrieved September 10, 2015, from http://digital.library.okstate.edu/oas/oas_pdf/v58/p110.pdf.

Eimanifar, A. \& Mohebbi, F. (2007). Urmia Lake (Northwest Iran): a brief review. Saline Systems, 3(5). Doi: 10.1186/1746-1448-3-5.

Gheorghievici, L. Gheorghievici, G., \& Tanase, I. (2015). The phytoplankton composition features of five romanian pelogenous ecosystems. Environmental Engineering and Management Journal, 14(5), 975-984. Retrieved September 11,2015,fromhttp://omicron.ch.tuiasi.ro/EEMJ/pdfs/vol14/no5/2_28_Gheorghi evici_12.pdf.

Giurgiu, I. (2010). Cea mai mare peşteră în sare din lume. Natura României, 3(21). Retrieved September 10, 2015, from www.romania-natura.ro

Hammer, T.U. (1981). Primary Production in Saline Lakes: A review. In W. Williams (ed.), Developments in Hydrobiolohy: Salt Lakes (pp. 47-58). Hague, the Netherlands: Dr. D.W. Junk Publishers.

Hammer, T.U. \& Heseltine, M. (1988). Aquatic macrophytes in saline lakes of Canadian praires. In J.M. Melack (Ed.), Saline Lakes: Proceedings of the Third International Symposium on Inland Saline Lakes, held at Nairobi, Kenya, August 1985 (pp. 101-116). Dordrecht: Dr. W. Junk Publishers.

Hayden, H.S., Blomster, J., Maggs, C.A., Silva, P.C., Stanhope, M.J. \& Waaland, J.R. (2003). Linneus was right all along: Ulva and Enteromorpha are not distinct genera. European Journal of Phycology, 38, 277-294.

Horincar, V.-B., Parfene, G. \& Bahrim, G. (2011). Evaluation of bioactive compounds in extracts obtained from three romanian marine algae species. ACRomanian Biotechnological Letters, 16(6), 71-78. Retrieved September 10, 2015, from http://www.rombio.eu/rbl6vol16Supplement/10\%20HORINCAR\%20VICENT IU.pdf

Horotan, A. (2010). Studiul hidrobiologic pentru lacurile exterioare de la Ocna Sibiului. Brvkenthal Acta Mvsei, 3, 543-554.

Irimia, D.-N. \& Irimuş, I. (2012). The touristic area Lopătari-Mînzăleşti. The role of tourism in territorial development: V. International Conference: October 10, 2012, Gheorgheni, Romania (pp. 134-140). Cluj-Napoca: Presa Universitară Clujeană.

John, D.M., Whitton, B.A. \& Brook, A.J. (2002). The Freshwater Algal Flora of the British Isles: An Identification Guide to Freshwater and Terestrial Algae (Vol. I). Cambridge University Press.

John, D. \& Rindi, F. (2015). Filamentous (Nonconjugating) and Plantlike Green Algae. In J. Wehr, R. Sheath \& J. Kociolek (eds.), Freshwater Algae of North America: Ecology and Classification. Second edition, Volume 8 (pp. 375-422). Academic Press, Elsevier. 
Kaštovský, J., Hauer, T., Mareš, J., Krautová, M., Bešta, T., Komárek, J., Zapomělov, E. (2010). A review of the alien and expansive species of freshwater cyanobacteria and algae in the Czech Republic. Biological Invasion, 12, 3599 3625 .

Legea 5/06.03.2000 privind aprobarea Planului de amenajare a teritoriului național Secțiunea a III-a, Zone protejate. Monitorul Oficial al României, nr. 152/ 12.04.2000.

Leskinen, E. \& Pamilo, P. (1997). Evolution of the ITS Sequences of Ribosomal DNA in Enteromorpha (Chlorophyceae). Hereditas, 126(1), 17-23.

Leskinen, E., Alström-Rapaport, C. \& Pamilo, P. (2004). Phytogeographicalstructure, distribution and genetic variation of the green algae Ulva intestinalis and $U$. compressa (Chlorophyta) in the Baltic Sea. Molecular Ecology, 13, 2257-2265.

Mareš, J., Leskinen, E., Sitkovska, M., Skacelova, O. \& Blomster, J. (2011). True identity of the European freshwater Ulva (Chlorophyta, Ulvophyceae) revelead by a combined molecular and morphological approach. Journal of Phycology, 47(5), 1177-1192.

Mărunţeanu, C. \& Ioane, D. (2010). Salt Karst in Manzalesti - Romania. In N Evelpidou, T. de Figueiredo, F. Mauro, V. Tecim, \& A. Vassilopoulos (Eds.), Natural Heritage from East to West: Case studies from 6 EU countries (pp. 105-110). Berlin Heidelberg: Springer \& Business Media,

Messyasz, B. (2009). Enteromorpha (Chlorophyta) populations in the Nielba Riverand Lake Laskownickie. Oceanological and Hydrobiological Studies, International Journal of Oceanography and Hydrobiology, 38(Supplement), 1-9.

Messyasz, B., \& Rybak, A. (2008). Macroalga Ulva intestinalis L. occurrence in freshwater of Poland: a new locality in Wielkopolska. Teka Kom. Ochr. Kszt. Środ. Przyr. - OL PAN, 5, 126-135. Retrieved July 12, 2015, from http://www.pan-ol.lublin.pl/wydawnictwa/TOchr5/Messyasz.pdf.

Messyasz, B., \& Rybak, A. (2009). The distribution of green algae species from the Ulva genera (syn. Enteromorpha; Chlorophyta) in Polish inland waters. Oceanological and Hydrobiological Studies, International Journal of Oceanography and Hydrobiology, 38(1), 121-138.

Messyasz, B. \& Rybak, A. (2011). Abiotic factors affecting the development of Ulva sp. (Ulvophyceae; Chlorophyta) in freshwater ecosystems. Aquatic Ecology, 45, 75-87.

Messyasz, B., Czerwi-Marcinkowska, J., Massalski, A., Uher, B., Rybak, A., Szendzina, L. \& Pikosz, M. (2013). Morphological and ultrastructural studies on Ulva flexuosa subsp. pilifera (Chlorophyta) from Poland. Acta Societatis Botanicorum Poloniae, 82(2), 157-163.

Messyasz, B., Pikosz, M., Schroder, G., Leska, B. \& Fabrowska, J. (2015). Identification and ecology of macroalgae species existing in Poland. In S.-K. Kim, \& K. Chojnacka (Eds.), Marine Algae Extracts: Processes, Products, and Applications. Volume 1 (pp. 17-40). Weinheim, Germany: John Wiley \& Sons.

Millán, A., Velasco, J., Gutiérrez-Cánovas, C., Arribas, P., Picazo, F., SánchezFernández, D. \& Abellán, P. (2011). Mediterranean saline streams in southeast Spain: What do we know? Journal of Arid Environment, 75, 1352-1359. 
Moore, K.A. (2009). Submerged Aquatic Vegetation of the York River. Journal of Coastal Research, Special Issue (57), 50-58.

Nastac, M., Gheorghiu, K. \& Mihu, I. (2014). Characteristics of macro-algae biomass from Romanian Black Sea Coast. In W.M. Petre Gâş̧tescu (ed.), 2nd International Conference-Water Resources and Wetlands (pp. 383-387). Tulcea. Retrieved September 10, 2015, from http://www.limnology.ro/water2014/proceedings/52_Nastac.pdf

OM MMDD nr. 1964/2007 (Ordinul Ministrului Mediului și Dezvoltării Durabile nr. 1964/2007 privind regimul de arie naturală protejată a siturilor de importanță comunitară. ROSCI0199 Platoul Meledic, Formularul Standard NATURA 2000. Monitorul Oficial al României nr. 98 bis/ 07.02.2008, pg. 1058-1060.

Pfester, L.A., Felkner, O.P. \& Felkner, W.O. (1976). Enteromorpha, a marine alga in oklahoma. Proc. Okla. Acad. Sci., 56. Retrieved September 11, 2015, from http://digital.library.okstate.edu/oas/oas_pdf/v56/p66.pdf

Reinke, D.C. (1981). Enteromorpha, a marine alga in Kansas. Transactions of the Kansas Academy of Sciences, 84(4), 228-230.

Rybak, A., Messyasz, B., Szendzina, L., Szendzina, L., Pikosz, M. \& Koperski, M. (2011). A new locality of the freshwater population of of Ulva flexuosa subsp. pilifera (Chlorophyta, Ulvophyceae) in Poznań (Wielkopolska). Teka Kom. Ochr. Kszt. Środ. Przyr. - OL PAN, 8, 131-144.

Sava, D., Arcuş, M. \& Doroftei, E. (2010). Preliminary data on Meledic-Mânzăleşti Natural Reserve (Buzau county, Romania). Analele Universității Ovidius, Seria Biologie-Ecologie, 14, 61- 66.

Savage, C. (1964). Lake Rezaiyeh: a specialised summer habitat for Shelduck and Flamingos. Wildfowl \& Wetlands Trust, Fifteenth Annual Report, pp. 108-113.

Taft, C.E. (1964). The occurence of Monostroma and Enteromorpha in Ohio. The Ohio Journal of Science, 64(4), 272-274. Retrieved September 30, 2014, from http://hdl.handle.net/1811/5018.

Tan, I., Blomster, J., Hansen, G., Leskinen, E., Maggs, C., Mann, D., Stanhope, M. (1999). Molecular Phylogenetic Evidence for a Reversible Morphogenetic Switch Controlling the Gross Morphology of Two Common Genera of Green Seaweeds, Ulva and Enteromorpha. Molecular Biology and Evolution, 16(8), 1011-1018.

Velasco, J., Millán, A., Hernández, J., Gutiérrez, C., Abellán, P., Sánchez, D. \& Ruiz, M. (2006). Response of biotic communities to salinity changes in a Mediterranean hypersaline stream. Saline Systems, 2(12), 1-15.

Vladimirescu, A. (2007). Optical microscopy, TEM and molecular investigation on freswater Enteromorpha in Romania. European Journal of Phycology, 42(sup 1), 85-171.

Zimmermann-Timm, H. (2007). Salinisation of inland waters. Water uses and human impacts on the water budget. Postdam, Germany. Retrieved September 12, 2015, from https://www.pik-potsdam.de/members/heike/zimmermanntimm2007.pdf. 